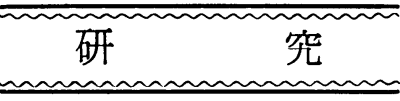

\title{
スズーニッケル合金めっきの熱安定性に及ぼす 合金組成の影響
}

\author{
榎本 英彦*，藤原 裕*，伊崎 昌伸*，尾野 博三**
Relationship between Thermal Stability and Alloy Composition of Metastable Tin-Nickel Electrodeposits

Hidehiko ENOMOTO*, Yutaka FUJIW ARA*, Masanobu IZAKI*, Hiromitsu ONO*

\begin{abstract}
Transformation upon heating of electrodeposited metastable tin-nickel alloys, prepared from pyrophosphate baths, was studied by means of differential thermal analysis and X-ray diffraction. Metastable tin-nickel alloys were obtained as a single phase (NiSn) in the composition range from 40 to $55 \mathrm{at} . \% \mathrm{Sn}$. Alloys containing $49-55 \mathrm{at} . \% \mathrm{Sn}$ were transformed exothermically into mixed or single equilibrium phases of $\mathrm{Ni}_{3} \mathrm{Sn}_{2}+\mathrm{Ni}_{3} \mathrm{Sn}_{4}$ or $\mathrm{Ni}_{3} \mathrm{Sn}_{4}$. Tin-nickel alloys with higher tin content had lower transformation temperature ; e.g., they were transformed at below $100^{\circ} \mathrm{C}$ for 55 at. $\% \mathrm{Sn}$, whereas at $340^{\circ} \mathrm{C}$ for $49 \mathrm{at} . \% \mathrm{Sn}$. Tin-nickel alloys containing $40-44 \mathrm{at} . \% \mathrm{Sn}$ were transformed to a single phase of $\mathrm{Ni}_{3} \mathrm{Sn}_{2}$ at $c a .300^{\circ} \mathrm{C}$ with no distinct heat evolution, corresponding to the transformation. Tin-nickel alloys ( 47 at.\% Sn) electrodeposited from fluoride baths were transformed at $360^{\circ} \mathrm{C}$ into another supersaturated metastable phase. The intermediate metastable phase was decomposed into mixed equilibrium phases of $\mathrm{Ni}_{8} \mathrm{Sn}_{2}+\mathrm{Ni}_{8} \mathrm{Sn}_{4}$ at $600^{\circ} \mathrm{C}$.
\end{abstract}

\section{1. 緒言}

スズーニッケル合金めっき皮膜は優れた耐食性を持ち， 装飾用，防食用，電子部品用として広く用いられてい る。現在，スズーニッケル合金めっき浴としてはフッ化 物浴およびピロリン酸浴が工業化されており，標準的な 浴組成, 電解条件のフッ化物浴からはニッケル：スズが 重量比で35：65(原子比でほぼ 1：1) 1), ピロリン酸浴 からは28：72 (原子比ではほぼ $3 ： 4$ ) 2)の電着物が得ら れる。これらの電着物は，ともに六方晶 $\mathrm{NiAs}$ 型結晶構 造を持つ単一の中間相 NiSnである ${ }^{3), 4) 。 ~}$

$\mathrm{NiSn}$ 相は平衡状態図 ${ }^{5)}$ にはあらわれない準安定相で あるため，熱処理によって平衡相への変態を起こす。フ ッ化物浴から得られた $\mathrm{Ni}: \mathrm{Sn}=1 ： 1$ 組成の電着物の 熱安定性についてはいくつかの報告がある6 ${ }^{6) 。 ま た ， ~}$ Wynne ${ }^{10)}$ は 1：1よりニッケル含有率が大きい $\mathrm{Ni}$ : Sn 組成範囲について, Augis ら ${ }^{11}$ は 1: 1 組成の近傍に ついて，それぞれ準安定相の熱安定性と合金組成の関係 を報告している。しかし，ピロリン酸浴からの電着物の 熱安定性に関する研究，特よび $\mathrm{Ni}: \mathrm{Sn}=1 ： 1$ よりス

* 大阪市立工業研究所（开536 大阪市城東区森之宮16-50)

Osaka Municipal Technical Research Institute (6-50, Morinomiya-1 chome, Joto-ku, Osaka 536)

** 同所受託研究員
ズ含有率が大きい場合の熱安定性と合金組成の関係につ いての研究はみられない。

本報では，ピロリン酸浴を用いて種々の組成のスズー ニッケル合金電着物を作成し，NiSn 相が単相で得られ る全組成範囲について，その熱安定性と合金組成の関係 を示差熱分析と X線回折によって検討した。さらに， フ ッ化物浴からの電着物との比較を行なった。

\section{2. 実 験 方 法}

試料の作製に用いたスズーニッケル合金めっき浴の浴 組成を表 1 亿示した。合金組成の異なる試料を得るため に, 塩化スズと塩化ニッケルの合計濃度を $0.25 \mathrm{M}$ とし て，これらの濃度を変化させた種くの組成のピロリン酸 浴を調製した。F浴が工業的に用いられている標準的な 組成のピロリン酸浴である。

浴温度をピロリン酸浴では $50^{\circ} \mathrm{C}, フ ッ$ 化物浴では $70^{\circ} \mathrm{C}$ として, 無かくはん, 電流密度 $0.5 \mathrm{~A} / \mathrm{dm}^{2}$ で電解した。 陽極には，ピロリン酸浴では白金めっきチタン板を用 い,フッ化物浴ではスズ板とニッケル板を分離させて用 いた。陰極には，銅板またはあらかじめ 10vol\% の硝酸 に浸せきして不動態化させたステンレス板を用いた。ス テンレス板上に，電解時間 4 時間30分として電着させた めっき皮膜を，折り曲げることによって素地からはく離 した後，めのう乳鉢で粉砕し，組成分析，示差熱分析， 
Table 1 Composition of tin-nickel alloy plating baths.

\begin{tabular}{|c|c|c|c|c|c|c|c|c|c|}
\hline \multirow{2}{*}{ Bath } & \multicolumn{8}{|c|}{ Pyrophosphate } & \multirow{2}{*}{ Fluoride } \\
\hline & A & B & $\mathrm{C}$ & D & $\mathrm{E}$ & $\mathrm{F}$ & G & $\mathrm{H}$ & \\
\hline $\mathrm{SnCl}_{2} \cdot 2 \mathrm{H}_{2} \mathrm{O}$ & $0.025 \mathrm{M}$ & $0.038 \mathrm{M}$ & $0.050 \mathrm{M}$ & $0.075 \mathrm{M}$ & $0.100 \mathrm{M}$ & $0.125 \mathrm{M}$ & $0.150 \mathrm{M}$ & $0.175 \mathrm{M}$ & $50 \mathrm{~g} / \mathrm{l}$ \\
\hline $\mathrm{NiCl}_{2} \cdot 6 \mathrm{H}_{2} \mathrm{O}$ & $0.225 \mathrm{M}$ & $0.212 \mathrm{M}$ & $0.200 \mathrm{M}$ & $0.175 \mathrm{M}$ & $0.150 \mathrm{M}$ & $0.125 \mathrm{M}$ & $0.100 \mathrm{M}$ & $0.075 \mathrm{M}$ & $250 \mathrm{~g} / \mathrm{l}$ \\
\hline glycine & $0.450 \mathrm{M}$ & $0.425 \mathrm{M}$ & $0.400 \mathrm{M}$ & $0.350 \mathrm{M}$ & $0.300 \mathrm{M}$ & $0.250 \mathrm{M}$ & $0.200 \mathrm{M}$ & $0.150 \mathrm{M}$ & - \\
\hline $\mathrm{K}_{4} \mathrm{P}_{2} \mathrm{O}_{7}$ & $0.500 \mathrm{M}$ & $0.500 \mathrm{M}$ & $0.500 \mathrm{M}$ & $0.500 \mathrm{M}$ & $0.500 \mathrm{M}$ & $0.500 \mathrm{M}$ & $0.500 \mathrm{M}$ & $0.500 \mathrm{M}$ & - \\
\hline $\mathrm{NH}_{4} \cdot \mathrm{HF}_{2}$ & - & - & - & - & - & - & - & - & $50 \mathrm{~g} / l$ \\
\hline
\end{tabular}

$\# \mathrm{pH}=2.5$, adjusted with $\mathrm{NH}_{4} \mathrm{OH}$

Table 2 Alloy composition of deposits.

\begin{tabular}{|c|c|c|c|}
\hline \multirow{2}{*}{ Bath } & \multicolumn{2}{|c|}{ Alloy composition(at, \%) } & \multirow{2}{*}{$\begin{array}{l}\text { Symbol } \\
\text { of deposit }\end{array}$} \\
\hline & $\mathrm{Ni}$ & $\mathrm{Sn}$ & \\
\hline Pyrophosphate & & & \\
\hline $\mathrm{A}$ & 64 & 36 & $36 \mathrm{Sn}$ \\
\hline B & 60 & 40 & $40 \mathrm{Sn}$ \\
\hline $\mathrm{C}$ & 56 & 44 & $44 \mathrm{Sn}$ \\
\hline $\mathrm{D}$ & 51 & 49 & $49 \mathrm{Sn}$ \\
\hline $\mathrm{E}$ & 48 & 52 & $52 \mathrm{Sn}$ \\
\hline $\mathrm{F}$ & 45 & 55 & $55 \mathrm{Sn}$ \\
\hline G & 42 & 58 & $58 \mathrm{Sn}$ \\
\hline $\mathrm{H}$ & 39 & 61 & $61 \mathrm{Sn}$ \\
\hline Fluoride & 53 & 47 & $47 \mathrm{Sn}$ \\
\hline
\end{tabular}

X線回折のための試料とした。また，銅 板上に 1 時間電着させた板状試料の X線 回折を行なった。

粉末にした試料を濃塩酸一過酸化水素 水混合溶液に溶解し, ジメチルグリオキ シム法によるニッケルの定量を行い, 残 量をスズとみなして合金組成を決定し た。

示差熱分析は, 熱分析装置（島津製作 所製，20B型）を用い，窒素気流中で行 なった。参照物質には $\alpha$-アルミナを用 い，昇温速度は $10^{\circ} \mathrm{C} / \mathrm{min}$ とした。

$\mathrm{X}$ 線回折は, 理学電機製 D3C-SG7 型 を用い, $\mathrm{FeK} \alpha$ 線 $(30 \mathrm{kV}, 10 \mathrm{~mA}, \mathrm{Mn}$ フ ィルター) によるディフラクトメーター 法で行なった。

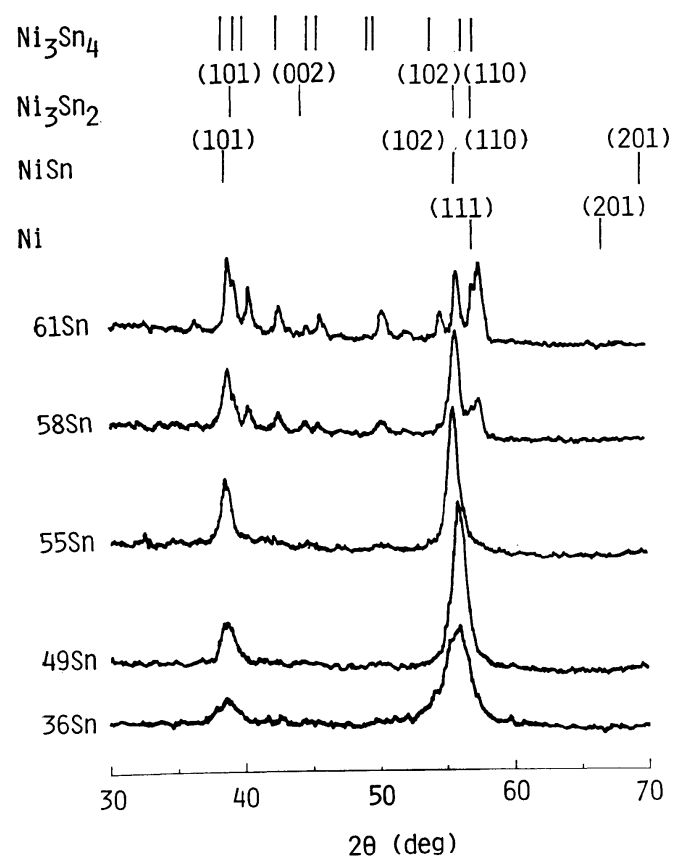

Fig. 1 X-ray diffraction patterns of electrodeposited tin-nickel in powder form.

\section{3. 実験結果および考察}

\section{3-1 合金組成と電着合金相}

得られた電着物の合金組成を表 2 に示した。以下の文 中では，表 2 に示したようにそれぞれの合金組成に対応 させて，たと壳ば 64at\% Ni-36at\% Sn 組成の電着物を 36Snなどと略記した。

電着物の代表的な X線回折パターンを図 1 および図 2 に示した。㘡にはニッケル, 準安定相 NiSn 扰よび平衡 相 $\mathrm{Ni}_{3} \mathrm{Sn}_{2}, \mathrm{Ni}_{3} \mathrm{Sn}_{4}$ の主な回折線（相対強度30以上）の位

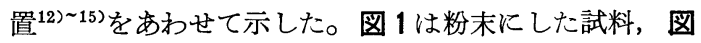
2 は銅板上にめっきしたままの板状試料の回折パターン である。粉末試料と板状試料の両方のX線回折パターン を考慮して電着合金相を同定した。

36Snには粉末試料では NiSnのブロードな回折線のみ がみられるが，板状試料では $64.9^{\circ}$ 亿も強い回折線がみ られる。この回折線がニッケル（200）面のものであると して計算したニッケルの格子定数は 3.61 Å注) であった。 この計算值から求められるニッケル (111) 面の回折角は $55.4^{\circ}$ であり, $55.5^{\circ}$ 付近のブロードな回折線はニッケル

注) SI 単位への換算 $1 \AA=10^{-10} \mathrm{~m}$ 
の (111) と, NiSn の(102), (110) 回折線が重なったも のであると考えられる。平衡状態ではニッケル中に固溶 するスズは $500^{\circ} \mathrm{C}$ 以下では 1 at\%以下であるが5)，田辺 ら ${ }^{16)}$ は電着合金ではスズはニッケル中に10at\%まで固溶 すると報告している。本実験でニッケルの格子定数とし

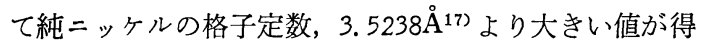
られたのは，このような過飽和固溶相が形成されたため と思われる。36Sn はスズを過飽和に 固溶したニッケル と NiSnの混合相であると考えられる。

40-55at\% Sn の組成範囲の電着物 (40Sn, 44Sn, 47 $\mathrm{Sn}, 49 \mathrm{Sn}, 52 \mathrm{Sn}, 55 \mathrm{Sn}$ ) では, 粉末試料からも板状試料か らも同様に NiSn のみが同定された。図 1 特よび図 2 に は 49Sn および55Snの回折パターンを示した。55Snは 工業的に用いられている標準組成のピロリン酸浴からの 電着物に相当する。粉末試料では, NiSn の (101) 回折 線と (102), (110) 回折線の相対強度はASTM カードの データ 13) と同じ傾向を示した。しかし，板状試料では， スズ含有率が52at\%以下の場合 $(40 \mathrm{Sn}, 44 \mathrm{Sn}, 47 \mathrm{Sn}, 49$ $\mathrm{Sn}, 52 \mathrm{Sn}$ ), (102) (110) 回折線のみが見られ, (101) 回 折線は現われなかった。一方, 55Snでは逆にASTMの データで相対強度80である (101) 回折線の強度が, 相対 強度100である (102)（110）回折線の強度より大さい。 このことから NiSn が単相で得られる合金組成範囲にお いても, 電着物の配向性は合金組成によって変化してい ることがわかる。

$\mathrm{NiSn}$ の単相形成範囲は文献によって多少異なり, Cuthbertson 53) ら を得ている。めっき浴と電解条件の違いを考慮すれば本 実験の結果（40-55at\% Sn）はこれらの文献值とよい一 致を示しており, 準安定相の単相形成範囲はほぼ $\mathrm{Ni}_{3} \mathrm{Sn}_{2}$ に相当する組成から $\mathrm{Ni}_{3} \mathrm{Sn}_{4}$ に相当する相成までに 及九 でいる。したがって，これらの電着合金が熱処理によっ て変態すると, $\mathrm{Ni}_{3} \mathrm{Sn}_{2}, \mathrm{Ni}_{3} \mathrm{Sn}_{4}$, またはそれらの混合相 に変化することが予想される。

$58 \mathrm{Sn}$ の粉末試料には, $\mathrm{NiSn}$ の回折線以外に $\mathrm{Ni}_{3} \mathrm{Sn}_{4}$ によると考えられる回折線が現われた。一方, 板状試料 では, NiSnの回折強度が大きいため $\mathrm{Ni}_{3} \mathrm{Sn}_{4}$ の回折線は みられず，55Sn と同様に(101) 面に優先配向した NiSn 単相の回折パターンを示している。また, 61Sn は粉末, 板状ともに複雑な回折パターンを示しているが，これは $\mathrm{NiSn}$ の回折線と $\mathrm{Ni}_{3} \mathrm{Sn}_{4}$ の回折線が重なったものである と考えられる。これらの試料は, その合金組成が平衡状 態に打ける $\mathrm{Ni}_{3} \mathrm{Sn}_{4}$ と $\beta-\mathrm{Sn}$ の 2 相領域に相当している が, $\mathrm{NiSn}+\mathrm{Ni}_{3} \mathrm{Sn}_{4}$ 混合相であると同定された。以上の結 果をまとめて，電着合金相と合金組成の関係を平衡相と ともに図 3 に示した。

\section{3-2 熱安定性}

NiSn が単相で得られた電着物(40-55at\% Sn) の示差 熱分析（DTA）を行なった。代表的なDTA曲線を図 4 に示す。スズ含有率 $47 \mathrm{at} \%$ 以上の電着物 $(47 \mathrm{Sn}, 49 \mathrm{Sn}$, 52Sn, 55Sn）の DTA 曲線には発熱ピークがみられた。 これらの試料の合金組成は，平衡状態での $\mathrm{Ni}_{3} \mathrm{Sn}_{2}$ と $\mathrm{Ni}_{3} \mathrm{Sn}_{4}$ の 2 相域または $\mathrm{Ni}_{3} \mathrm{Sn}_{4}$ の単相域に相当している。 発熱ピーク温度は, $47 \mathrm{Sn}$ では $360^{\circ} \mathrm{C}, 49 \mathrm{Sn}$ では $340^{\circ} \mathrm{C}$,

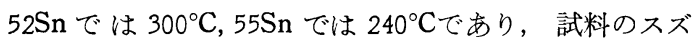
含有率が大きいほど低温で発熱が認められた。一方, $\mathrm{Ni}_{3} \mathrm{Sn}_{2}$ の組成に近い40Sn と 44Sn の DTA 曲線には明確 な発熱ピークはみられなかった。

これらの発熱ピークが電着物のどのような変化による ものかる調べるため, 発熱ピーク前後の種々の温度で熱 処理した粉末試料のX線回折を行なった。DTA 曲線と 対応させるため, 熱処理には，DTA 装置を用いて窒素 気流中昇温速度 $10^{\circ} \mathrm{C} / \mathrm{min}$ で加熱し, 所定の温度に達し た後ただらに試料セルから炉を取りはずして急冷した。 また明確な発熱ピークのみられなかった40Sn と44Sn に ついても $300^{\circ} \mathrm{C}, 400^{\circ} \mathrm{C}, 600^{\circ} \mathrm{C}$ の熱処理後の X 線回折を行 なった。 $300^{\circ} \mathrm{C} 400^{\circ} \mathrm{C}$ は，それぞれ49Sn の発熱ピーク の前後の温度に相当する。

55Sn の熱処理後のX線回折パターンを図 5 に示した。
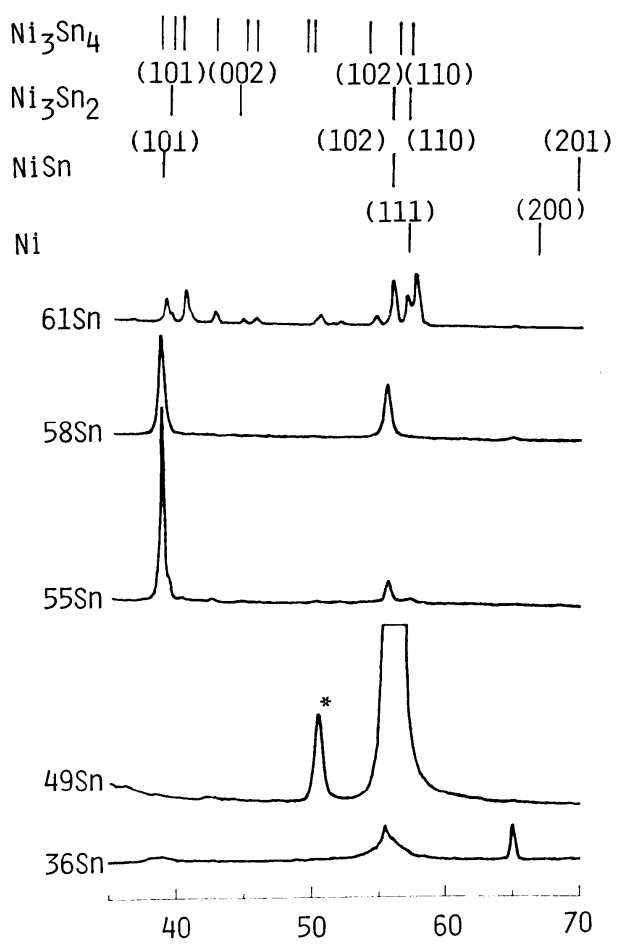

$2 \theta$ (deg)

Fig. 2 X-ray diffraction patterns of electrodeposited tin-nickel in film form.

* ; NiSn(102), (110) line due to $\mathrm{Fe} \mathrm{K} \beta$ 

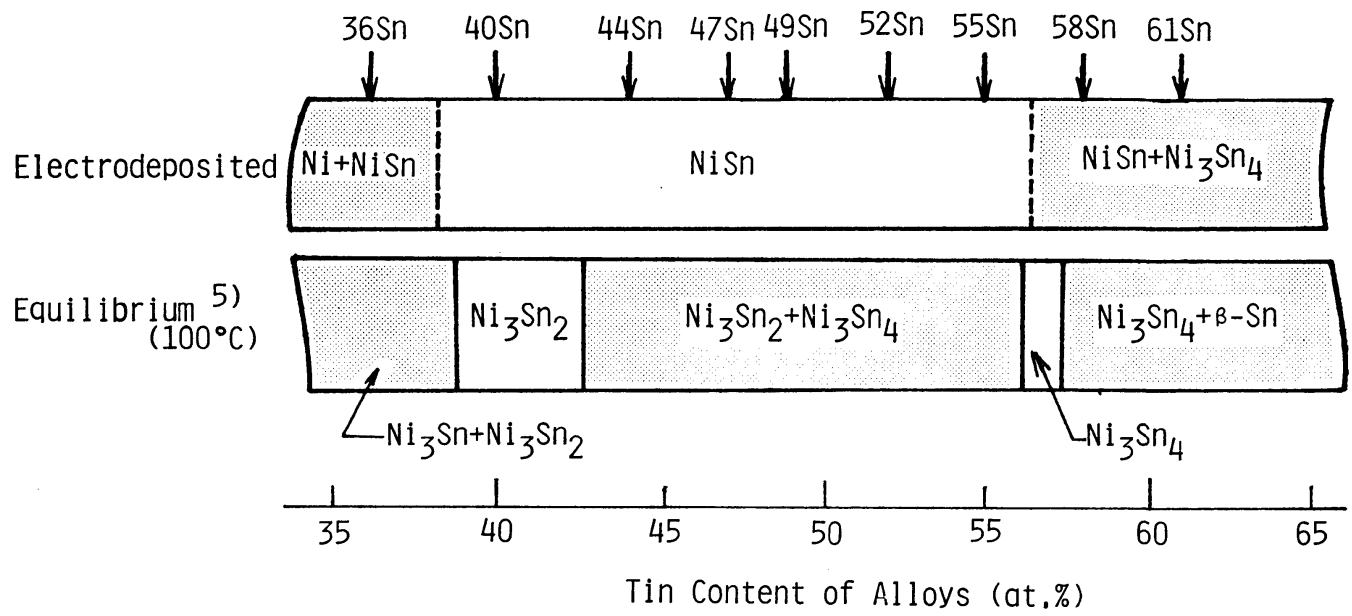

Fig. 3 Structure of electrodeposited and equilibrium tin-nickel alloys.

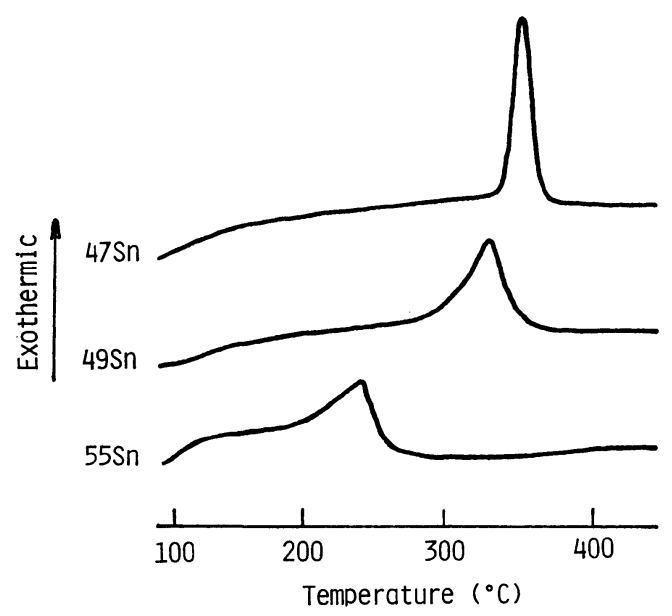

Fig. 4 DTA curves of electrodeposited tin-nickel.

55Sn の DTA 曲線は $100^{\circ} \mathrm{C}$ から $260^{\circ} \mathrm{C}$ にかけて立ち上が りの温度が不明確なブロードな発熱ピークを示したが，

$\mathrm{X}$ 線回折パターンは $100^{\circ} \mathrm{C}$ で変化している。熱処理によ って新たに現われた回折線は熱処理温度の上昇とともに シャープになり，この組成の平衡相である $\mathrm{Ni}_{3} \mathrm{Sn}_{4}$ が生 成したことを示している。

49Sn の熱処理後のX 線回折パターンを図 6 亿示した。 DTA 曲線に発熱ピークが 現われる直前の熱処理温度 $\left(300^{\circ} \mathrm{C}\right)$ で $\mathrm{NiSn}$ 単相の回折パターンに変化はみられな いが，熱処理温度が発熱ピークの温度より高い， $400^{\circ} \mathrm{C}$, $600^{\circ} \mathrm{C}$ では回折パターンは変化している。それぞれの回

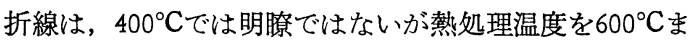
で上昇させるとシャープになり， $\mathrm{Ni}_{3} \mathrm{Sn}_{2}$ と $\mathrm{Ni}_{3} \mathrm{Sn}_{4}$ が重 なった回折パターンを示した。 $52 \mathrm{Sn}$ でも $49 \mathrm{Sn}$ と同様に $400^{\circ} \mathrm{C}$ の熱処理で回折パターンの変化がみられ，平衡状 態である $\mathrm{Ni}_{3} \mathrm{Sn}_{2}+\mathrm{Ni}_{3} \mathrm{Sn}_{4}$ 混合相への変態を示した。

$40 \mathrm{Sn}$ の熱処理前後の X線回折パターンを図 7 亿示し
た。DTA 曲線に明確な発熱ピークのみられなかった $40 \mathrm{Sn}$ の回折パターンは $300^{\circ} \mathrm{C}$ 熱処理後はほとんど変化

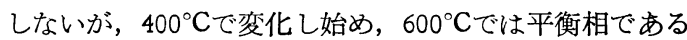
$\mathrm{Ni}_{3} \mathrm{Sn}_{2}$ 単相の回折パターンを示す。 $44 \mathrm{Sn}$ も同様に $600^{\circ} \mathrm{C}$ の熱処理後に $\mathrm{Ni}_{3} \mathrm{Sn}_{2}$ 単相の 回折パターンを示したが, 変態温度は40Sn より低く，300年で，すでに回折パター ンの変化がみられた。

以上の結果からピロリン酸浴から得られた NiSn 単相 の電着物について，(1) $\mathrm{Ni}_{3} \mathrm{Sn}_{2}+\mathrm{Ni}_{3} \mathrm{Sn}_{4}$ 混合相または $\mathrm{Ni}_{3} \mathrm{Sn}_{4}$ 単相への变態は明確な発熱を伴って起こること,

(2)この場合の変態温度は合金のスズ含有率が大きいほど 低く, $49 \mathrm{Sn}$ では約 $340^{\circ} \mathrm{C}, 55 \mathrm{Sn}$ では $100^{\circ} \mathrm{C}$ ですでに変態 を起こすこと，(3) $\mathrm{Ni}_{8} \mathrm{Sn}_{2}$ 単相への変態は約 $300^{\circ} \mathrm{C} て ゙$ 起こ るが, その際に明確な発熱はみられないことがわかった。

$\mathrm{NiSn}$ と $\mathrm{Ni}_{8} \mathrm{Sn}_{2}$ の結晶構造は，ともに六方晶 $\mathrm{NiAs}$ 型 であり, 格子定数の值も近い $(\mathrm{NiSn} ; \mathrm{a}=4.15 \AA, \mathrm{c}=$ 5. $\left.10 \AA^{13)}, \mathrm{Ni}_{3} \mathrm{Sn}_{2} ; \mathrm{a}=4.07 \AA, \mathrm{c}=5.15 \AA^{14)}\right)$ 。また, Augis ら ${ }^{111}$ は，準安定相 NiSn の生成と分解について次 のような考方方を提唱している。すなわち，NiSn は電 気めっきのような低温析出過程で $\mathrm{Ni}_{3} \mathrm{Sn}_{2}$ の核生成が 他 の中間相 $\left(\mathrm{Ni}_{3} \mathrm{Sn}, \mathrm{Ni}_{3} \mathrm{Sn}_{4}\right)$ より容易であるために組成範 囲が桩がった過飽和 $\mathrm{Ni}_{3} \mathrm{Sn}_{2}$ であり，その $\mathrm{Ni}_{3} \mathrm{Sn}_{2}+\mathrm{Ni}_{3} \mathrm{Sn}_{4}$ 混合相への分解は過飽和 $\mathrm{Ni}_{3} \mathrm{Sn}_{2}$ 母相中に打ける 第 2 の 平衡相 $\mathrm{Ni}_{3} \mathrm{Sn}_{4}$ の析出と成長であるとしている。本実験 で $\mathrm{NiSn}$ から単相の $\mathrm{Ni}_{3} \mathrm{Sn}_{2}$ への変態の際に明確な発熱が みられなかったのは，変態の前後の構造変化が小さいた めであり, $\mathrm{Ni}_{8} \mathrm{Sn}_{2}+\mathrm{Ni}_{3} \mathrm{Sn}_{4}$ 混合相への分解の際の発熱 は $\mathrm{Ni}_{3} \mathrm{Sn}_{4}$ の析出に対応しているものと思われる。また， $\mathrm{NiSn}$ すなわち 過飽和 $\mathrm{Ni}_{3} \mathrm{Sn}_{2}$ の 合金組成が平衡組成 $(\mathrm{Ni}: \mathrm{Sn}=3: 2)$ から大きくずれるほど平衡相への分 解, すなわち $\mathrm{Ni}_{3} \mathrm{Sn}_{4}$ の析出を起こしやすくなるため, NiSn のスズ含有率が大きいほど変態は低温で観測され 


\section{たものと考えられる。}

フッ化物浴からの電着物 $47 \mathrm{Sn} の, 300^{\circ} \mathrm{C}, 400^{\circ} \mathrm{C}$ 打よび $600^{\circ} \mathrm{C}$ での熱処理後のX線回折パターンを図 8 に示した。 $47 \mathrm{Sn}$ の合金組成は平衡状態における $\mathrm{Ni}_{3} \mathrm{Sn}_{2}+\mathrm{Ni}_{3} \mathrm{Sn}_{4}$ の 2 相域に相当する合金組成を持つピロリン酸浴からの電 着物49Sn と同様に, DTA 曲線の発熱ピーク前の温度, すなわち $300^{\circ} \mathrm{C}$ の熱処理では变化せず単相の $\mathrm{NiSn}$ を示 した。熱処理温度が発熱ピークより高温の $400^{\circ} \mathrm{C}$ の場合, 回折パターンは変化したが，ピロリン酸浴からの電着物 とは異なって，平衡状態の $\mathrm{Ni}_{3} \mathrm{Sn}_{2}+\mathrm{Ni}_{8} \mathrm{Sn}_{4}$ 混合相では なく単相の $\mathrm{Ni}_{3} \mathrm{Sn}_{2}$ を与えた。熱処理温度を $600^{\circ} \mathrm{Cにする}$ と, $\mathrm{Ni}_{3} \mathrm{Sn}_{4}$ によると考劣られる新たな回折線が現われ

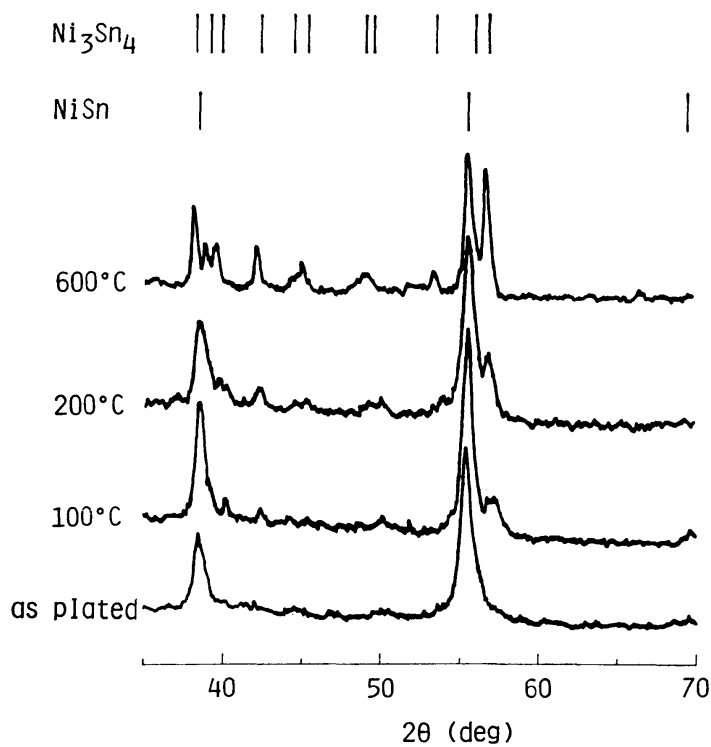

Fig. 5 X-ray diffraction patterns of $55 \mathrm{Sn}$ after heat treatment.

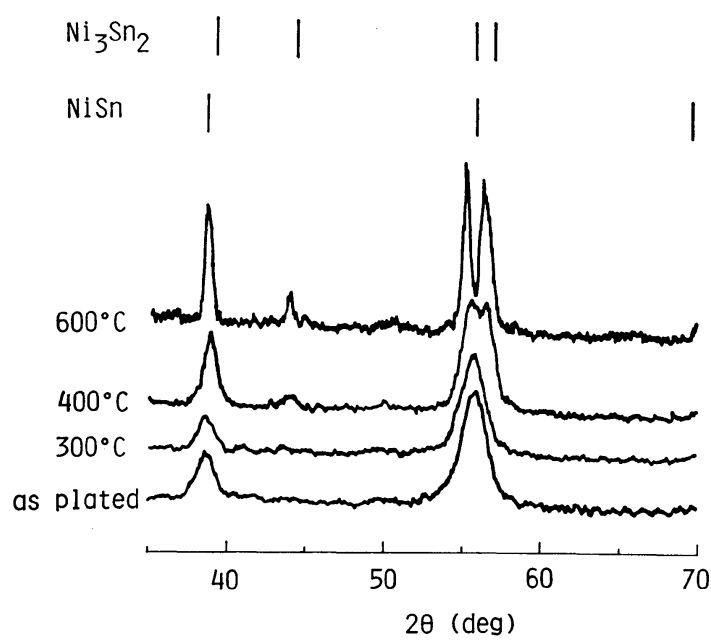

Fig. 7 X-ray diffraction patterns of $40 \mathrm{Sn}$ after heat treatment.
た。

Wynne ら ${ }^{10}$ は，(1) $\mathrm{Ni}_{3} \mathrm{Sn}_{2}+\mathrm{Ni}_{3} \mathrm{Sn}_{4}$ の 2 相域に相当 する合金組成の電着物は，急熱すると平衡相への分解に 先たって, NiSn とは別の単相の準安定相に変化するこ

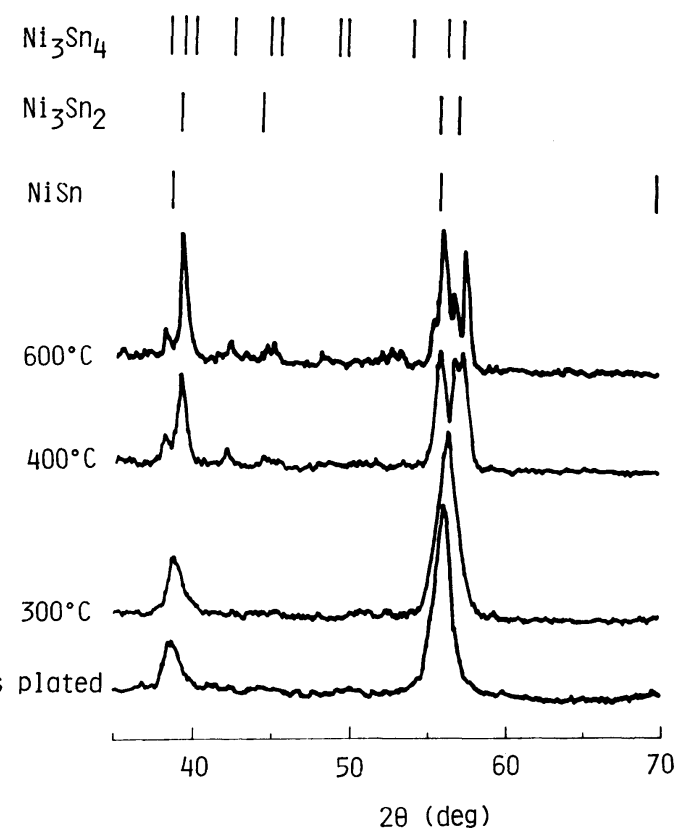

Fig. 6 X-ray diffraction patterns of $49 \mathrm{Sn}$ after heat treatment.

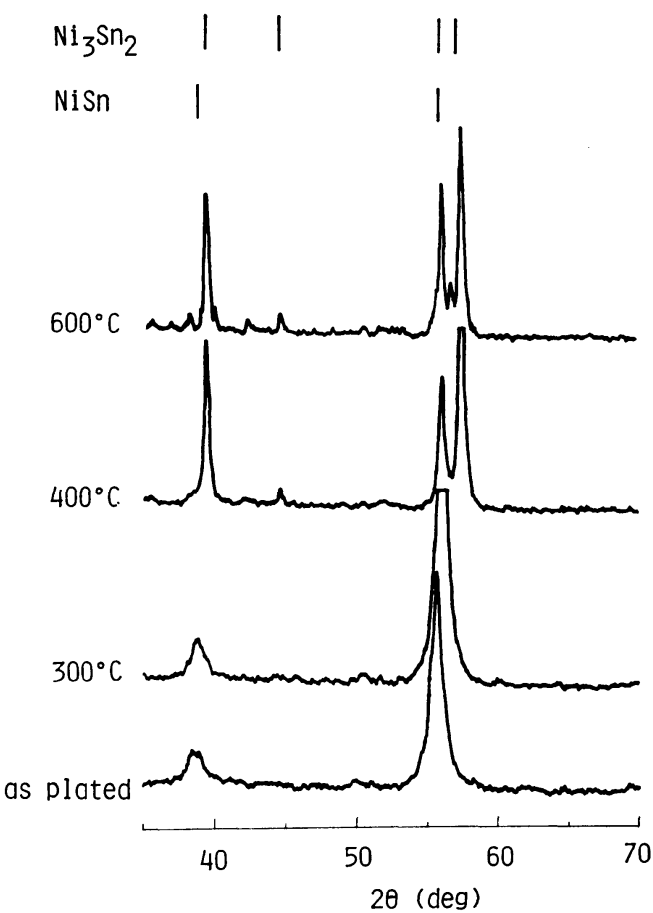

Fig. 8 X-ray diffraction patterns of $47 \mathrm{Sn}$ after heat treatment. 
と, (2)この準安定相は $\mathrm{NiSn}$ 扰よび $\mathrm{Ni}_{3} \mathrm{Sn}_{2}$ と同じく六 方晶 $\mathrm{NiAs}$ 型の結晶構造を持ち, その格子定数は $\mathrm{Ni}_{3} \mathrm{Sn}_{2}$

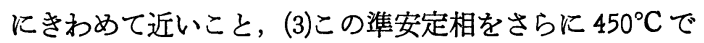
80分熱処理すると $\mathrm{Ni}_{8} \mathrm{Sn}_{4}$ の析出がみられること，を報 告している。本実験では, 熱処理の際の加熱速度は比較 的遅い $10^{\circ} \mathrm{C} / \mathrm{min}$ であったが,ここでみられた NiSn から 単相の $\mathrm{Ni}_{3} \mathrm{Sn}_{2}$ への変化は, Wynne らの報告している準 安定相の生成に対応していると思われる。

フッ化物浴からの電着物が，熱処理の際に平衡状態で ある $\mathrm{Ni}_{3} \mathrm{Sn}_{2}+\mathrm{Ni}_{3} \mathrm{Sn}_{4}$ 混合相への分解に先だって準安定 相に変化したことは，直接平衡相に分解したピロリン酸 浴からの電着物 $49 \mathrm{Sn}$ に比べて, $\mathrm{Ni}_{3} \mathrm{Sn}_{4}$ の析出, 成長の 速度が遅いことを示している。めっき浴の違いによって 電着物の変態過程が異なることは, Augis ら ${ }^{18}$ )がスパッ ター析出したスズーニッケル合金と電着スズーニッケル合 金の相違として指摘しているように, 微視的応力, 微細 構造，不純物等に差異があることを示唆している。

\section{4. 結 論}

ピロリン酸浴から種々の合金組成のスズーニッケル合 金電着物を作製し，電着準安定相 NiSn が単相で得られ た40-55at\% Sn の電着物を窒素気流中, 昇温速度 $10^{\circ} \mathrm{C} /$ minで加熱し，準安定相の熱安定性に括よぼす合金組成 の影響について検討した。また，フッ化物浴からの電着 物 $(47 \mathrm{at} \% \mathrm{Sn})$ との比較を行なった。

スズ含有率 40-44at\% の電着物は約 $300^{\circ} \mathrm{C}$ で 単 相の $\mathrm{Ni}_{3} \mathrm{Sn}_{2}$ に変化したが，その DTA 曲線には明確な発熱は みられなかった。スズ含有率 49-55at\% の電着物は, 明 瞭な発熱を伴って, 平衡相である $\mathrm{Ni}_{3} \mathrm{Sn}_{2}+\mathrm{Ni}_{8} \mathrm{Sn}_{4}$ 混合相 または $\mathrm{Ni}_{3} \mathrm{Sn}_{4}$ 単相に变化した。分解温度はスズ含有率 が大きいほど低温であった。フッ化物浴からの電着物の DTA 曲線には $360^{\circ} \mathrm{C}$ 付近に明膫な発熱がみられたが，こ れは平衡相への分解ではなく $\mathrm{Ni}_{8} \mathrm{Sn}_{2}$ と同じ結晶構造を 持つ準安定相への変化に対応していた。この準安定相 は, 熱処理温度を $600^{\circ} \mathrm{C}$ にすると平衡状態の $\mathrm{Ni}_{3} \mathrm{Sn}_{2}+$ $\mathrm{Ni}_{3} \mathrm{Sn}_{4}$ 混合相に分解した。

終わりに本研究を行うにあたり，いろいろ御教示くだ さった大阪府立大学工学部, 林忠夫教授に厚く批礼申し あげます。 (1982-2-26 受理)

（昭和56年 3 月, 本協会第63回学術講演大会にて発表）

\section{文献}

1) N. Parkinson; The Electrodeposition of Bright Tin-Nickel Alloy Plate, J. Electrodepositors' Tech. Soc., 27, 129 (1951)

2) 榎本英彦, 中川融；ピロリン酸浴によるスズーニッ ケル合金めっき，本誌，27，569（1976）
3) J.E.Cuthbertson, N.Parkinson and H.P.Rooksby; Electrodeposition of Tin-Nickel Alloy Plate from Chloride-Fluoride Electrolytes, J. Electrochem. Soc., 100, 107 (1953)

4) 榎本英彦, 石川正巳 ; ピロリン酸浴からのスズーニ ッケル合金めっきの耐食性, 本誌, 30，284 (1979)

5) M. Hansen and K. Anderko; Constitution of Binary Alloys, p. 1042, New York (1958, McGrawHill)

6) R.F. Smart and D.A. Robins; The Structural Stability of Tin-Nickel Electrodeposits, Trans. Inst. Met. Fin., 37, 108 (1960)

7) P.K. Dutta and M. Clarke ; Structure and Thermal Stability of Tin-Nickel Alloys Electrodeposited from Acid Baths, ibid., 46, 20 (1968)

8) J.E. Bennett and H.G. Tomkins; Investigation of an Electrodeposited Tin-Nickel Alloys 1. Thermal Stability by Differential Thermal Analysis and X-ray Diffraction, J. Electrochem. Soc., 123, 999 (1976)

9) J.A. Augis and J.E. Bennett; Kinetics of the Transformation of Metastable Tin-Nickel Deposits 1. Determination of the Avrami Equation Parameter by DSC or DTA, ibid., 125, 330 (1978)

10) B.E. Wynne, J.E. Edington and G.P. Rothwell; The Transformation on Annealing of the Metastable Electrodeposits, $\mathrm{NiSn}_{\mathrm{x}}$, to its Equilibrium Phases, Met. Trans., 3, 301 (1972)

11) J.A. Augis and J.E. Bennett; Kinetics of the Transformation of Metastable Tin-Nickel Deposits 2, Formation and Transformation Mechanisms, J. Electrochem. Soc., 125, 335 (1978)

12) A.S.T.M. Powder Diffraction Data Card ; No.40850 Nickel.

13) ibid; No. 7-256 Tin-Nickel Electrodeposits.

14) ibid; No. 6-0414 $\mathrm{Ni}_{3} \mathrm{Sn}_{2}$.

15) ibid; No. $4-0845 \mathrm{Ni}_{3} \mathrm{Sn}_{4}$.

16）田辺良美, 清水保雄; 電析 Ni-Sn 合金の 微細構造 と相に関する電子顕微鏡的研究，本誌，26，406(19 75)

17）日本金属学会編；金属 データブック，p. $44(1974$, 丸善)

18) J.A. Augis and J.E. Bennett; Sputter Deposition of a Metastable Equiatomic Tin-Nickel Alloy, J. Electrochem. Soc., 124, 1455 (1977) 